\title{
PHYLOGENETIC ANALYSIS AND ANTI MICROBIAL ACTIVITY OF Streptomyces spp. ISOLATED FROM COMPOST SOIL IN SURABAYA INDONESIA ON THE BASIS OF 16S Rrna GENE
}

\author{
R Kurnijasanti ${ }^{1}$, Isnaeni ${ }^{2}$, Poernomo AT ${ }^{2}$, SA Sudjarwo ${ }^{1}$ \\ ${ }^{1}$ Department of Basic Veterinary Medicine, Faculty of Veterinary, ${ }^{2}$ Department of Pharmacy Analysis, \\ Faculty of Pharmacy, Universitas Airlangga
}

\begin{abstract}
ABSTRAK
Delapan isolat Streptomyces sp. dapat diisolasi dari tanah kompos di Surabaya, Indonesia. Hasil uji biokimia dan morfologi menunjukkan bahwa 8 isolat tersebut merupakan isolat baru. Analisis filogenetik dilakukan berdasarkan sekuen gen 16S rRNA. Sekuen nukleotida dari gen 16S rRNA Streptomyces sp. isolat tanah kompos Surabaya dianalisis dan dibandingkan dengan sekuen gen $16 S$ rRNA dari pustaka. Hasil analisis Streptomyces sp. isolat tanah kompos Surabaya berdasarkan gen 16S rRNA menunjukkan Streptomyces spesies baru. Hasil diagram pohon filogenetik menunjukkan bahwa Streptomyces Sp-D, Sp-Ep, Sp-G dan Sp-I yang ditemukan pada tanah rumah kompos Bratang Surabaya ternyata merupakan isolat baru. Streptomyces Sp-Ep merupakan Streptomyces jenis baru yang masih berkerabat dekat dengan Streptomyces indonesiasis dan Streptomyces nashvillensis. Streptomyces Sp-Ea merupakan Streptomyces olivoreticuli yang masih berkerabat dengan Streptomyces yogyakartensis. Streptomyces Sp-F adalah Streptomyces levis strain NRRL B-24299. Streptomyces Sp-C adalah Streptomyces filamentosus. Streptomyces Sp-D merupakan Streptomyces jenis baru yang masih berkerabat dekat dengan Streptomyces javensis dan Streptomyces roseus. Streptomyces Sp-G merupakan Streptomyces jenis baru yang masih berkerabat dekat dengan Streptomyces roseoviridis strain NBRC 12911 dan Streptomyces thermocarboxydovorans strain AT52. Streptomyces Sp-I merupakan Streptomyces jenis baru yang masih berkerabat dekat dengan Streptomyces cangkringensis dan Streptomyces asiaticus. Streptomyces Sp-A adalah Streptomyces laurentii strain : LMG 19959. (FMI 2017;53:204-208)
\end{abstract}

Kata kunci: analisis filogenetik; antimikrobial; streptomises; tanah kompos; $16 S$ rRNA

\begin{abstract}
Eight isolates of Streptomyces sp. can be isolated from compost soil in Surabaya, Indonesia. The results of biochemical and morphological tests showed that the 8 isolates were new. Phylogenetic analysis was performed on the sequence of 16S rRNA gene. Nucleotide sequences of $16 \mathrm{~S}$ rRNA gene Streptomyces sp. the compost soil isolates of Surabaya were analyzed and compared with the $16 S$ rRNA gene sequence from the literature. Streptomyces sp. the compost soil of Surabaya based on the 16S rRNA gene showed the new species of Streptomyces. The result of phylogenetic tree diagram showed that Streptomyces $S p-D, S p-E p, S p-G$ and $S p-I$ found in Bratang Surabaya compost house land were new isolates. Streptomyces Sp-Ep was a new type of Streptomyces closely related to Streptomyces indonesiasis and Streptomyces nashvillensis. Streptomyces Sp-Ea was Streptomyces olivoreticuli which was still related to Streptomyces yogyakartensis. Streptomyces Sp-F was Streptomyces levis strain NRRL B-24299. Streptomyces Sp-C was Streptomyces filamentosus. Streptomyces $S p-D$ was a new type of Streptomyces closely related to Streptomyces javensis and Streptomyces roseus. Streptomyces Sp-G was a new type of Streptomyces closely related to Streptomyces roseoviridis strain NBRC 12911 and Streptomyces thermocarboxydovorans strain AT52. Streptomyces Sp-I was a new streptomyces that was still closely related to Streptomyces cangkringensis and Streptomyces asiaticus. Streptomyces Sp-A was Streptomyces laurentii strain: LMG 19959. (FMI 2017;53:204-208)
\end{abstract}

Keywords: Phylogenetic analysis; antimicrobial; streptomyces; compost soil; $16 S$ rRNA

Correspondence: R Kurnijasanti, Department of Basic Veterinary Medicine, Faculty of Veterinary, Universitas Airlangga. Email: santisam99@yahoo.co.id

\section{INTRODUCTION}

Streptomyces is largest genus of actinomycetes and constitute $50 \%$ of the total population of soil actinomycetes. Moreover, Streptomyces spp. provides a larger number and wider variety of new antibiotics than any other actinomycetes genera, suggesting that substantial numbers of Streptomyces species or strains with novel antibiotic productivity exist in nature. Furthermore, over 6000 antibiotics are obtained by different species of Streptomyces and many of these compounds are commercially available as anti-infective (antibiotics, antifungal and antiparasitic), anticancer or immunosuppressant agents (Champness 2000, Xiao et al 2002, Barakate et al 2002, Iznaga et al 2004). One spesies of Streptomyces is capable in producing more than 2-3 
natural-derived antibiotics. Tens of thousands of such compounds have been isolated and characterized, most of them have been developed into drugs for treatment of widerange of diseases in human, veterinary and agriculture.

Conventional classification methods for the identification of species within the genus Streptomyces have mainly relied on the morphological and phenotypic characteristics of the organisms. During the last decade, molecular biological methods such as 16S rRNA gene sequencing and BOX-PCR fingerprinting have had an increasing impact on streptomycete taxonomy (Kim \& Goodfellow 2002, Kim et al 2004, Saintpierre et al 2003).

In this study, we determined 16S rRNA gene sequences to classify Streptomyces spp. and Antimicrobial Activity isolates from compost soil in Surabaya, Indonesia. Therefore, a study on 16S rRNA gene sequence of antibiotic-producing Streptomyces spp. isolated from compost soil in Surabaya, Indonesia should be conducted. The objective of this study was to find new types of Streptomyces from compost soil in Surabaya, Indonesia which are immune, specific, and able to produce antibiotics as alternative drugs.

\section{MATERIALS AND METHODS}

Microorganisms and culture conditions

Eight Streptomyces spp could be isolated from soil sample collected from compost soil Surabaya, Indonesia. Streptomyces were isolated using ISP-4 agar. The plates were incubated for 4 days at $28^{\circ} \mathrm{C}$. The isolated Streptomyces spp were then screened since the have the potential to generate bioactive compounds. The most potent producer strains was then selected and identified. The cultures were maintained on ISP-4 agar. The inoculated agar medium was incubated for 4 days at $28^{\circ} \mathrm{C}$, then maintained at $4^{\circ} \mathrm{C}$ until further use.

Test microorganisms

Pseudomonas aeroginosa ATCC 27853, Eschericia coli ATCC 2593, Bacillus subtillis ATCC 6633, Staphylococcus aureus ATCC 25923 and Candida albicans ATCC 10231 were used to determine anti-microbial activity of isolated Streptomyces strains.

Screening of Actinomycetes for antimicrobial activity

The screening method consisted of steps as primary screening and secondary screening. In primary screening the antimicrobial activity of pure isolates were determined by perpendicular streak method on nutrient agar (NA). The test organisms were Pseudomonas aeroginosa ATCC 27853, Eschericia coli ATCC 2593, Bacillus subtillis ATCC 6633, Staphylococcus aureus ATCC 25923 and Candida albicans ATCC 10231. Secondary screening was done through the agar well method against the standard test organisms Pseudomonas aeroginosa ATCC 27853, Eschericia coli ATCC 2593, Bacillus subtillis ATCC 6633, Staphylococcus aureus ATCC 25923 and Candida albicans ATCC 10231 (Dhanasekaran et al 2005).

Primary screening of the antimicrobial activity

The primary antimicrobial activity was done by perpendicular streak method. In this method bacterial colonies were streaked on center of nutrient agar plates as a linear culture and incubated at $28^{\circ} \mathrm{C}$ for 4 days. After 4 days, the test microorganisms were inoculated perpendicularly to the linear cultures and incubated at $37^{\circ} \mathrm{C}$ for $48 \mathrm{~h}$. The antimicrobial producer isolates inhibited the growth of test microorganisms and were selected for further experiments (Dhanasekaran et al 2005).

\section{Secondary screening}

Secondary screening of potent actinomycetes was done to confirm the results of primary screening. A loopful of the Streptomyces spp. from the 4-day culture age was inoculated into $250 \mathrm{ml}$ Erlenmeyer flasks containing $100 \mathrm{ml}$ of liquid ISP-4 medium. The flasks were incubated on a rotary shaker $(200 \mathrm{rpm})$ at $28^{\circ} \mathrm{C}$ for 4 days. Two-liter of total volume was filtered through Whatman No.1 filter paper, followed by centrifugation at 5000 r.p.m at $10^{\circ} \mathrm{C}$ for 20 minutes. Culture supernatants was prepared and used for antimicrobial analyses, minimum inhibitory concentration. Secondary screening was performed by the agar well diffusion method against Pseudomonas aeroginosa ATCC 27853, Eschericia coli ATCC 2593, Bacillus subtillis ATCC 6633, Staphylococcus aureus ATCC 25923 and Candida albicans ATCC 10231.

Molecular assays

In order to identify the strains of the isolated Streptomyces and isolation of Streptomyces species among them, several molecular and bioinformatical assays were performed.

\section{Genomic DNA extraction}

Genomic DNA extraction was conducted according to the protocol described by Corbin method with some modifications. Briefly, a single colony was cultured in $50 \mathrm{ml}$ liquid ISP4 medium for 18 - 24 hours in shaker 
incubator at $28^{\circ} \mathrm{C}$. Then the culture was centrifuged for 3 minutes at $5000 \mathrm{rpm}$ and supernatant was discarded. The bacterial cells were pulverized in liquid nitrogen, suspended in a solution I containing $10 \mathrm{mM}$ Tris $(\mathrm{pH}$ : 7.4), $1 \mathrm{mM}$ EDTA, $0.5 \%$ SDS and $0.1 \mathrm{mg} / \mathrm{ml}$ of proteinase $\mathrm{K}$, and lysed by incubation at $37^{\circ} \mathrm{C}$ for 1 hour, then the solution II containing $0.8 \mathrm{M} \mathrm{NaCl}$ and $1 \%$ CTAB was added to the lysates, and incubated at $65^{\circ} \mathrm{C}$ for 20 min and extracted with equal volume of chloroform isoamylalcohol (24:1). Nucleic acid was precipitated from the aqueous phase with 0.6 volume of isopropanol and finally purified using ethanol $70 \%$ (Corbin et al 2001).

Amplification and sequencing of 16S rRNA gene

PCR amplification of the 16S rRNA gene of the local Streptomyces strain was conducted using two primers, StrepF; 5.- AGAGTTTGATCCTGKGTCAG -3.and Strep R; 5.AAGGAGGTGATCCAKKGKGA -3, (Davelos et al 2004). The PCR mixture consisted of 30 pmol of each primer, $100 \mathrm{ng}$ of chromosomal DNA, 200 $\mu \mathrm{M}$ dNTPs and 2.5 units of Taq polymerase, in $50 \mu 1$ of polymerase buffer. The PCR amplification was achieved at $94^{\circ} \mathrm{C}$ for 1 minute as primary denaturing temperature, then $94^{\circ} \mathrm{C}$ for 1 minute as denaturing temperature, $57^{\circ} \mathrm{C}$ for 60 seconds as annealing temperature, $72^{\circ} \mathrm{C}$ for 60 seconds as extension time, in 35 cycles, and $72^{\circ} \mathrm{C}$ for 5 minutes as final extension time. The PCR, reaction mixture was then analyzed via agarose gel electrophoresis and marked using $1 \mathrm{~kb}$ DNA ladder (Fermentas Co.) as the size marker. The remaining mixture was purified using QIA quick PCR purification reagents (Qiagen, USA). The 16S rRNA gene was sequenced on both strands via the dideoxy chain termination method. The 16S rRNA gene $(1.5 \mathrm{~kb})$ sequence of the PCR product was acquired using a Terminator Cycle Sequencing kit (ABI Prism 310 Genetic Analyzer, Applied Biosystems, USA).
Sequence similarities and phylogenetic analysis

The BLAST program (www.ncbi.nlm.nih.gov/blst) was used in order to assess the degree of DNA similarity. Multiple sequence alignment and molecular phylogeny were evaluated using MEGA 5.0 software (Tamura et al 2011). The phylogenetic tree was displayed using TREE VIEW program.

Identification of Streptomyces isolate

The identification was performed basically according to the recommended international Key's viz. and Numerical taxonomy of Streptomyces species program. On the basis of the $16 \mathrm{~S}$ rRNA.

\section{RESULTS}

The data results showed that different morphological of eight streptomyces were isolated from compost soil in Surabaya, Indonesia. The results of morphological observations are shown in Table 1.

\section{DISCUSSION}

The 16S rRNA gene sequences were compared to sequences in the public database using basic local alignment search tool (BLAST) on the National Center for Biotechnology Information (NCBI) website (http:// www.ncbi.nlm.nih.gov/) in order to determine similarity between sequences in the GenBank database (Shayne et al 2003). The $16 \mathrm{~S}$ rRNA gene sequences with high similarities to those determined in the study were retrieved and used in the construction of phylogenetic tree.

Table 1. Characteristics of Streptomyces spp.

\begin{tabular}{cccc}
\hline \multirow{2}{*}{ Isolate } & \multicolumn{3}{c}{ Characteristics } \\
\cline { 2 - 3 } & Colony color & Colony form & Colony surface \\
\hline Sp-A & white & round & Smooth, flat \\
Sp-C & creamy & Round, small & Smooth, convex \\
Sp-D & gray & round & convex \\
Sp-Ea & gray & round & flat \\
Sp-Ep & white & round & convex, shiny \\
Sp-F & pink & Round like a flower & uneven \\
Sp-G & pink & round & flat \\
Sp-I & gray & round & Smooth, shiny \\
\hline
\end{tabular}


Table 2. Antimicrobial activity of strains against test organisms

\begin{tabular}{cccccc}
\hline \multicolumn{7}{c}{ Inhibition zone $(\mathrm{mm})$} \\
\cline { 1 - 5 } Isolate & $\begin{array}{c}\text { E. coli } \\
\text { ATCC 2593 }\end{array}$ & $\begin{array}{c}\text { P. aeroginosa } \\
\text { ATCC 27853 }\end{array}$ & $\begin{array}{c}\text { B. subtillis } \\
\text { ATCC 6633 }\end{array}$ & $\begin{array}{c}\text { S. aureus } \\
\text { ATCC 25923 }\end{array}$ & $\begin{array}{c}\text { C. albicans } \\
\text { ATCC 10231 }\end{array}$ \\
\hline Sp-A & 13.7 & 13.7 & 12.7 & 12.7 & 14.7 \\
Sp-C & - & - & - & 6.1 & 0 \\
Sp-D & - & 7.1 & - & - & 7.9 \\
Sp-Ea & - & 9.1 & - & - & 7.8 \\
Sp-Ep & - & - & - & - & 5.5 \\
Sp-F & 13.4 & 14.8 & 12.9 & 11.6 & 14.7 \\
Sp-G & 13.9 & 12 & 11.1 & 11.6 & 14.8 \\
Sp-I & - & 5.9 & 6.9 & 5.7 & 9.3 \\
\hline
\end{tabular}

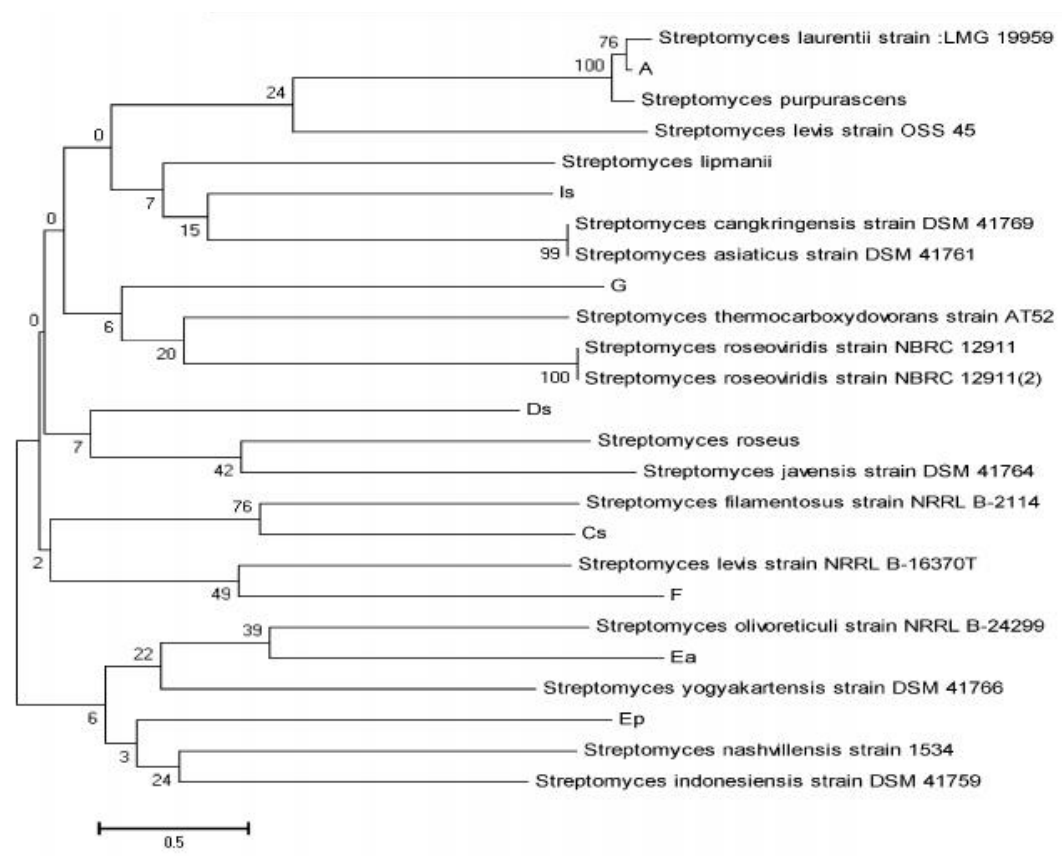

Fig. 1. phylogenetic tree based on 16S rRNA gene sequences

Phylogenetic analysis of Sp-A, Sp-C, Sp-D, Sp-Ea, SpEp, Sp-F, Sp-G, Sp-I strains revealed that they were belonged to the genus Streptomyces comparing with some of the type strains validly described and Indonesian local isolates was selected as an outgroup (Figs. 1). They were closed to the strains of $S$. laurentii LMG 19959, S. purpurascens, S. lewis OSS 45, S. lipmanii, S. cangkringensis DSM 41761, S. thermocarboxydovorans AT 52, S. roseoviridis NBRC 12911, S. Roseus, S. javensis DSM 41764, S. filamentosus NRRL B-2114, S. lewis NRRL B-16370T, S. olivoreticuli NRRL B-24299, S. yogyakartensis DSM 41766, S. nashwillensis 1555534 and S. indonesiensis DSM 41759.
The results showed that Streptomyces Sp-Ep clustered closely with Streptomyces indonesiasis and Streptomyces nashvillensis which was a new type. Streptomyces sp-Ea should be identified as Streptomyces olivoreticuli that was related to the Streptomyces yogyakartensis. Streptomyces sp-F should be identified Streptomyces levis strain NRRL B-24 299. Streptomyces sp-C should be identified Streptomyces filamentosus. Streptomyces sp-D was a new type that was closely related to Streptomyces javensis and Streptomyces roseus. Streptomyces sp-G was a new type that was closely related to Streptomyces roseoviridis strain NBRC12911 and Streptomyces thermocarboxydovorans strain AT52. Streptomyces sp-I was a new type that was still closely related to Streptomyces cangkringensis and Streptomy- 
ces asiaticus. Streptomyces sp-A should be identified Streptomyces laurentii strain LMG 19959. Basically, all the samples are the same genus Streptomyces with different types. Phylogenetic tree Streptomyces spp. can be seen in Figure 1.

\section{CONCLUSION}

The analysis of Streptomyces spp. from compost soil of Surabaya based on the 16S rRNA gene revealed new Streptomyces species. Phylogenetic tree diagram showed that Streptomyces Sp-D, Sp-Ep, Sp-G and Sp-I found in the soil from Bratang compost house Surabaya were new isolates.

\section{REFERENCES}

Barakate M, Ouhdouch Y, Oufdou K, Beaulieu C (2002). Characterization of rhizospheric soil streptomycetes from Moroccan habitats and their antimicrobial activities. World J. Microbiol. Biotechnol 17, 49-54

Champness W (2000). Actinomycete development, antibiotic production and phylogeny: questions and challenges. In: Brun YV and Skimkets LJ (ed.). Prokaryotic Development. Washington D.C, The American Society for Microbiology, p 11-31

Corbin DR, Grebenok RJ, Ohnmeiss TE, Greenplate JT, Purcell JP (2001). Expression and chloroplast targeting of cholesterol oxidase in transgenic tobacco plants. Plant Physiol 126, 1116-1128
Davelos AL, Xiao K, Samac DA, Kinkel LL (2004). Spatial variation in the frequency and intensity of antibiotic interaction among streptomycetes in a prairie soil. Appl Environ Microbiol 70, 1051-1058

Dhanasekaran D, Rajakumar G, Sivamani P, Selvamani S, Panneerselvam A, Thajuddin N (2005). Screening of salt pans actinomycetes for antibacterial agents. Int. J. Microbiol 1, 6-12

Iznaga Y, Lemus M, Gonzalez L, Garmendia L, Nadal L, Vallin C (2004). Antifungal activity of actinomycetes from Cuban soils. Phytother. Res. 18, 494-496

Kim SB, Goodfellow M (2002). Streptomyces avermitilis sp. nov., nom. rev., a taxonomic home for the avermectin-producing streptomycetes. Int J Syst Evol Microbiol 52, 2011-2014

Kim SB, Seong CN, Jeon SJ, Bae KS, Goodfellow M (2004). Taxonomic study of neutrotolerant acidophilic actinomycetes isolated from soil and description of Streptomyces yeochonensis sp. nov. Int J Syst Evol Microbiol 54, 211-214

Saintpierre D, Amir H, Pineau R, Sembiring L, Goodfellow M (2003). Streptomyces yatensis sp. nov., a novel bioactive streptomycete isolated from a NewCaledonian ultramafic soil. Antonie van Leeuwenhoek 83, 21-26.

Shayne JJ, Hugenholtz P, Sangwan P, Osborne C, Janssen HP (2003). Laboratory cultivation of widespread and previously uncultured soil bacteria. App. Environ. Microbiol 69, 7211-7214

Tamura K, Peterson D, Peterson N, et al (2011). MEGA 5: Molecular evolutionary distance and maximum parsimony methods. Mol Biol Evol 28, 27312739 